\title{
METHODOLOGY FOR SELECTING SOFTWARE FiLTERS
}

\author{
Dana Kubátová, Martin Melichar, Jan Kutlwašer
}
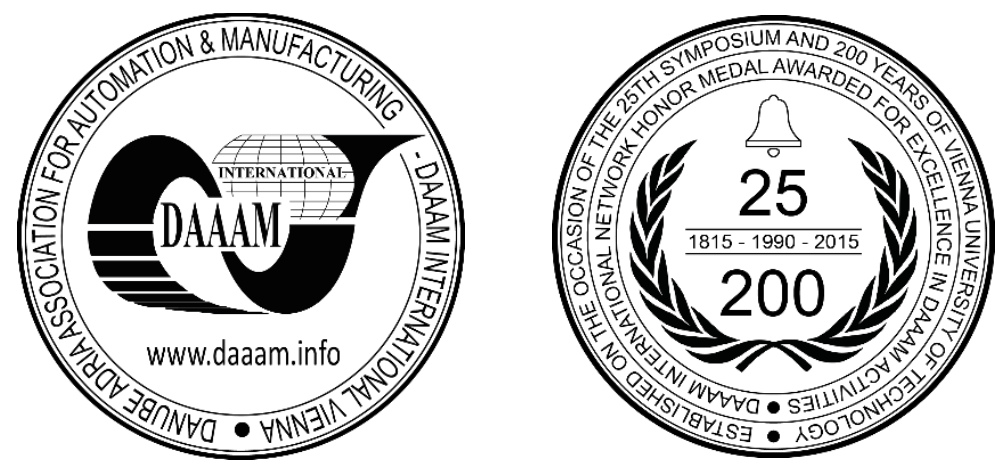

This Publication has to be referred as: Kubatova, D[ana]; Melichar, M[artin] \& Kutlwaser, J[an] (2018). Methodology for Selecting Software Filters, Proceedings of the 29th DAAAM International Symposium, pp.1266-1272, B. Katalinic (Ed.), Published by DAAAM International, ISBN 978-3-902734-20-4, ISSN 1726-9679, Vienna, Austria DOI: $10.2507 / 29$ th.daaam.proceedings.182

\begin{abstract}
The development of measurements and the evaluation of the surface structure has been marked by significant qualitative technical progress in recent years. Leading manufacturers of measuring technology (Hommel CS s.r.o., Carl Zeiss, Ltd., etc.) actively responded to new requirements. The development of measuring technology is also significantly influenced by the technical needs of users and their economic possibilities. To meet all the requirements of the Surface Structure Assessment, it is necessary to keep up with time and to keep under control new possibilities and knowledge from the field of measurement and assessment of surface integrity. And implement this knowledge into real usage conditions. In the area described by this article, the choice of software filters is not so. And as the main reason is the little awareness and great complexity of choosing the right combination of possible techniques and software filtering techniques.
\end{abstract}

Keywords: software filter; surface roughness; etalons; stylus; feed rate; statistical processing

\section{Introduction}

The purpose of this dissertation, as presented in its introduction, was to develop a method for selecting software filters for surface roughness measurement. Based on findings from tests I and II, graphs shown in Figures 1 through 4 were constructed which show the effects of software filters on data measured on surfaces of different roughnesses. The graphs present the similarity of the data measured using various software filters numbered 1 through 5 ( 1 - filter 4768 ; 2 - 0601; 3 - 16610-21; 4 - 16610-22; 5 - 16610-31), including their dissimilarity levels.

Figures 8-1 through 8-4 suggest that the effect of a filter grows stronger with increasing roughness of the surface measured. This can be seen on Y axes in Figures 8-1 through 8-4. The values of the $\mathrm{Y}$ axis indicate the dissimilarity between the results. With the RA 0.5 standard, the maximum is 0.05 . For the highest roughness used, RA 6.3, the value is as high as 1.2. The graphs also suggest that the most similar results, i.e. those with lowest variances, can be obtained with filter 3 (16610-21). In order to obtain a maximum measured value, filter 1 is the best choice (filter 4768). Details are given in chapter 7.1. These findings apply to a 2-micrometre stylus. [1,2,4,6] 


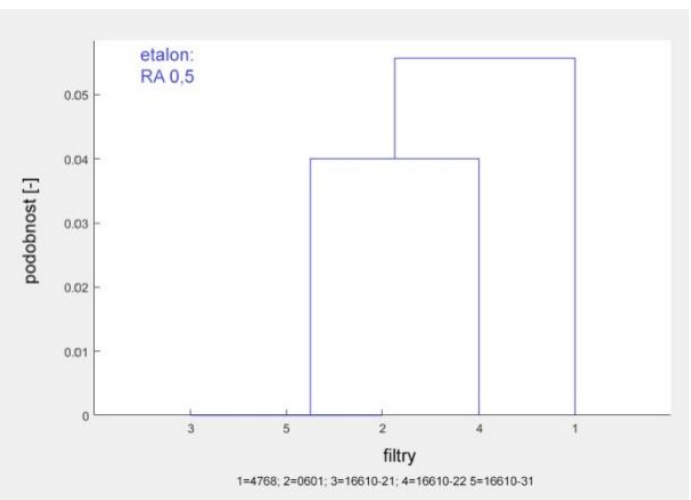

Fig. 1. Graph of results for filters under test and RA 0.5 standard

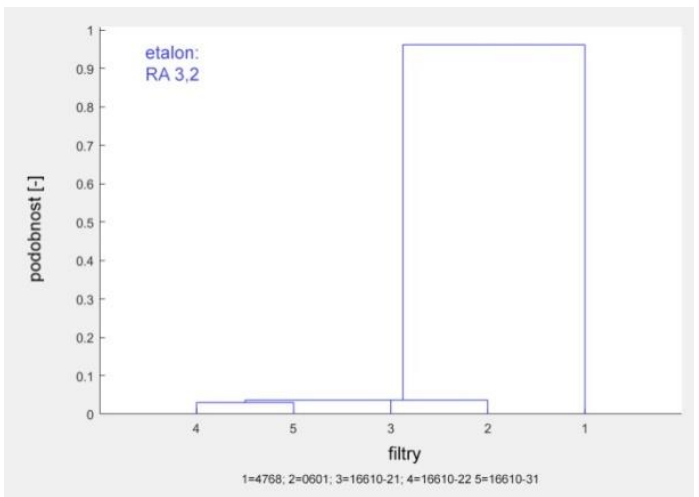

Fig. 3. Graph of results for filters under test and RA 3.2 standard

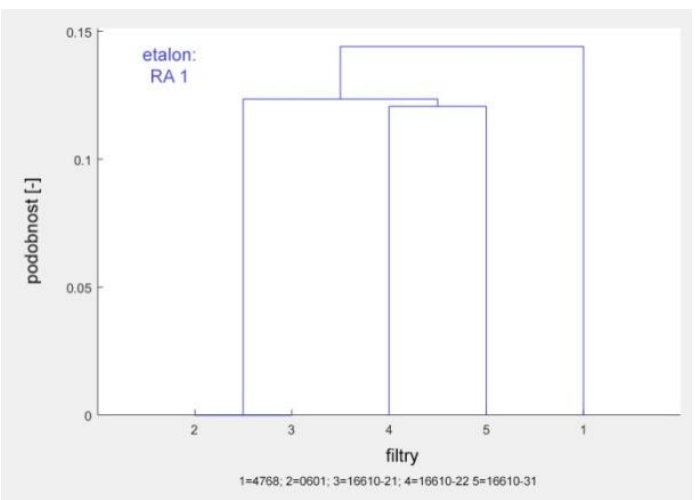

Fig. 2. Graph of results for filters under test and RA 1 standard

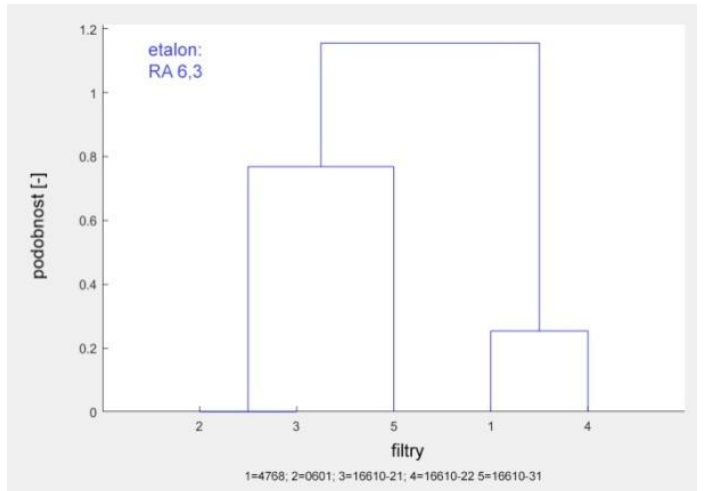

Fig. 4. Graph of results for filters under test and RA 6.3 standard

The evaluation of the effect of the stylus used for testing software filters is illustrated in Figure 5. The figure includes the initial filters numbered 1 to 5 and the same filters with numbers from 6 to 10. The first group applies to measurement with a 2-micrometre stylus, whereas the latter to a measurement with a 5-micrometre stylus. In Figure 5, the results for the 2-micrometre filter are closer to each other and the variance between the filters is smaller than with the stylus whose tip had a radius of 5 micrometres. In addition, the graph shows that the dissimilarity between results for 2-micrometre and 5-micrometre styluses is 1.5. [5]

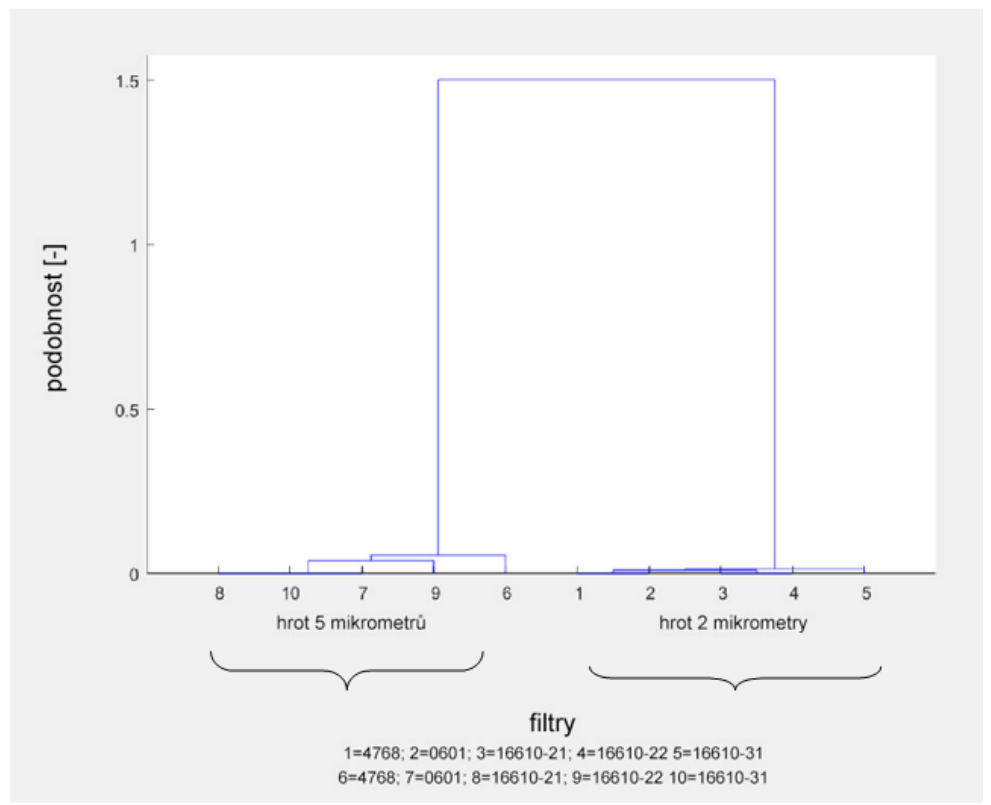

Fig. 5. Graph of results for filters and styluses under test 
Another important aspect regarding the method of selection of software filters for roughness measurement is the number of points to be used for measuring the primary profile to ensure that the real surface is evaluated, instead an artificial one obtained with an inadequate number of points.

Graphs in Figures 6 through 10 show the results of application of filters to averaged data with different numbers of points for various roughness numbers. The graphs clearly show that the appropriate spacing between (number of) points for measurement varies with a type of filter. [7,8]

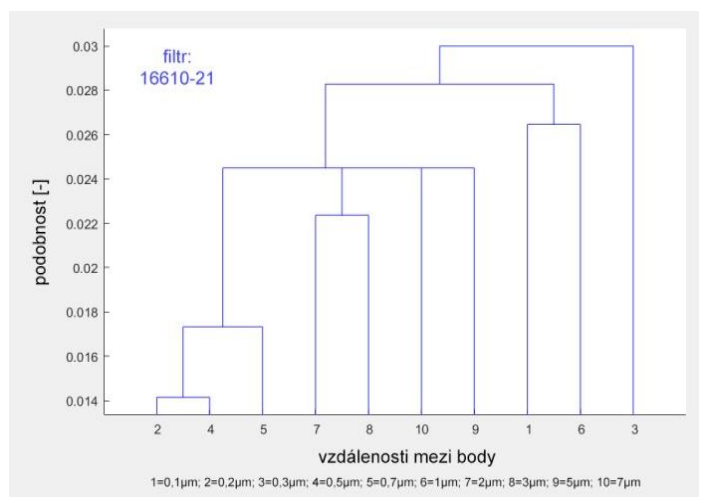

Fig. 6. Effects of the spacing between points with filter 16610-21

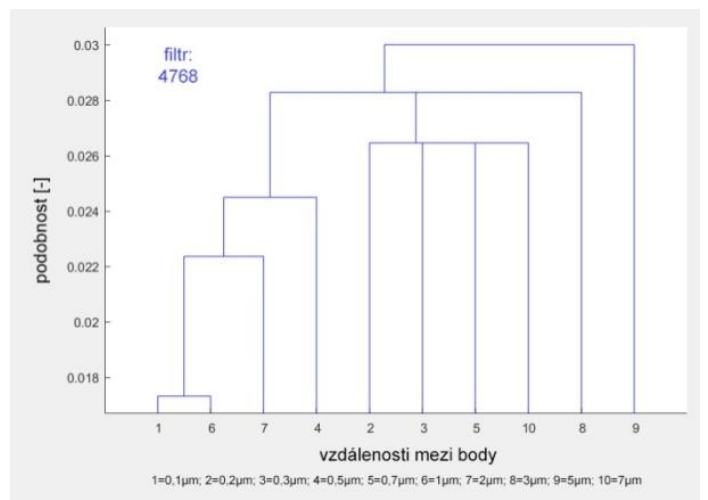

Fig. 8. Effects of the spacing between points with filter 4768

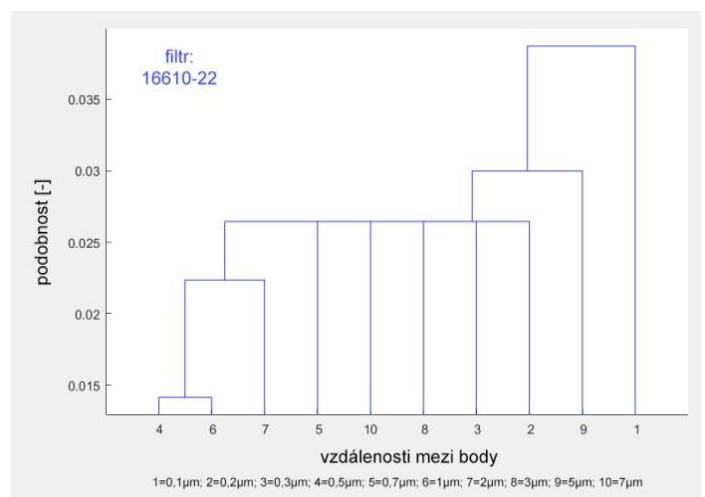

Fig. 7. Effects of the spacing between points with filter 16610-22

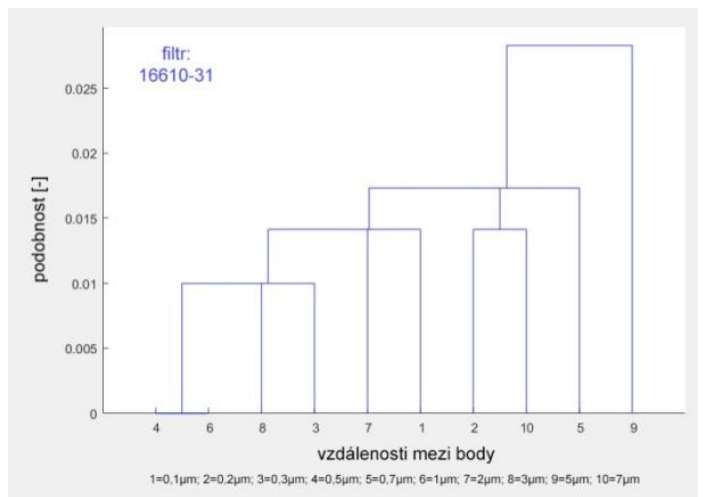

Fig. 9. Effects of the spacing between points with filter 16610-31

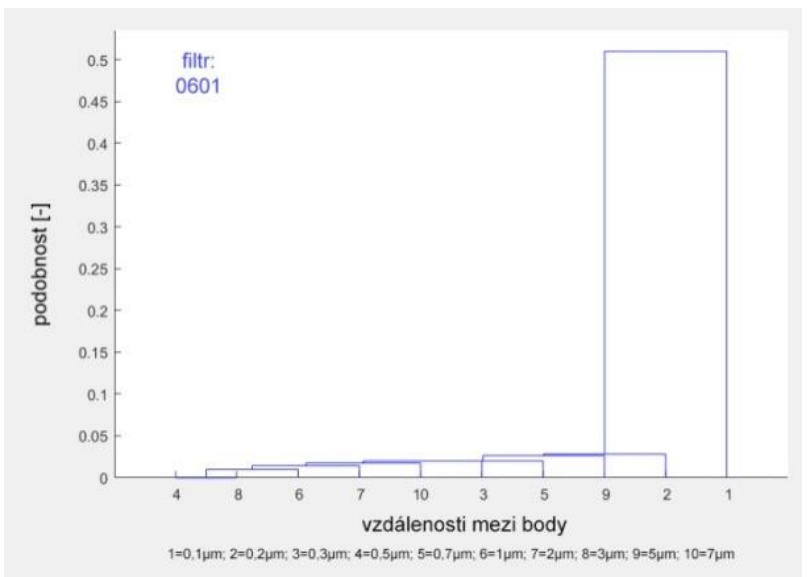

Fig. 10. Effects of the spacing between points with filter 0601

A measuring speed was the last aspect with effects on the choice of software filters which was tested. In this test, a statistical analysis of data proved the effects of software filters with only two out of four surface roughness parameters. Graphs in Figures 11 and 12 were constructed from average values of Rv and Rz parameters. In these graphs, the differences related to both parameters are nearly identical. [2,7] 


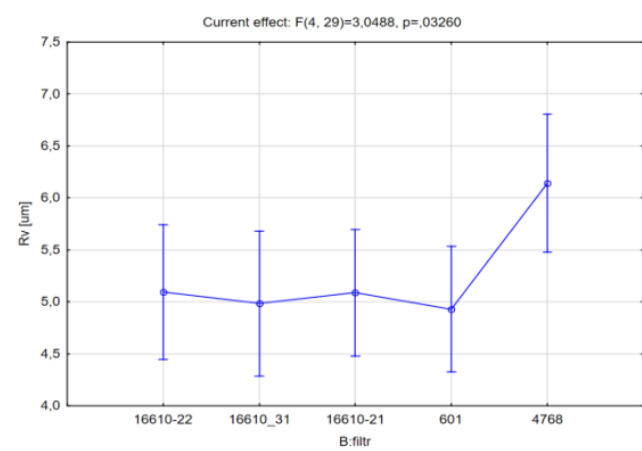

Fig. 11. Measurement with various speeds and filters

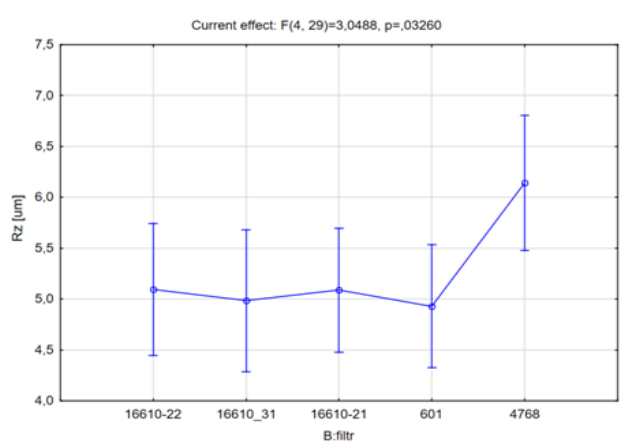

Fig. 12. Measurement with various speeds and filters

At the same time, test III was intended to provide data for confirming/rejecting the above-described findings. Based on the experiment planned for test III, the effects of selection of software filters were evaluated. The ANOVA analysis with MATLAB software was employed for the verification.

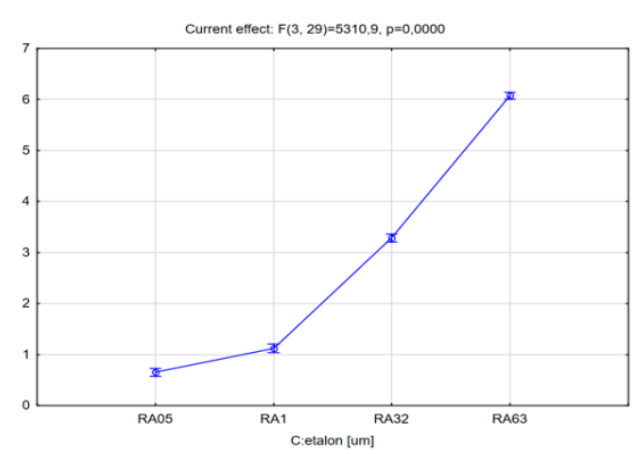

Fig. 13. Effect of 16610-21 filter after a change in surface roughness

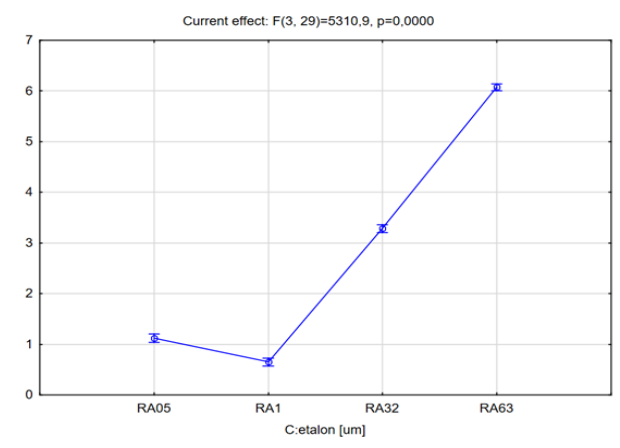

Fig. 15. Effect of 16610-31 filter after a change in surface roughness

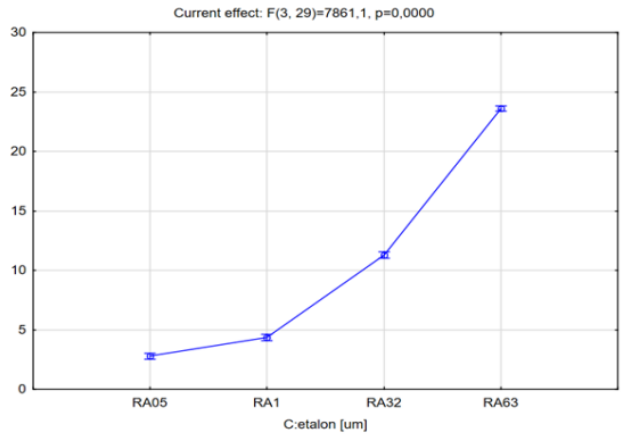

Fig. 14. Effect of 16610-22 filter after a change in surface roughness

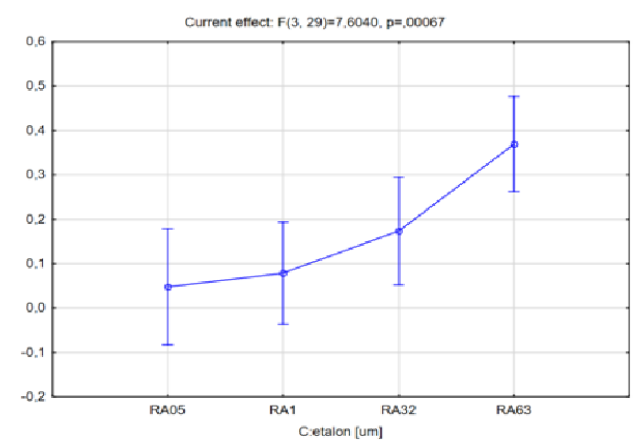

Fig. 16. Effect of 4768 filter after a change in surface roughness

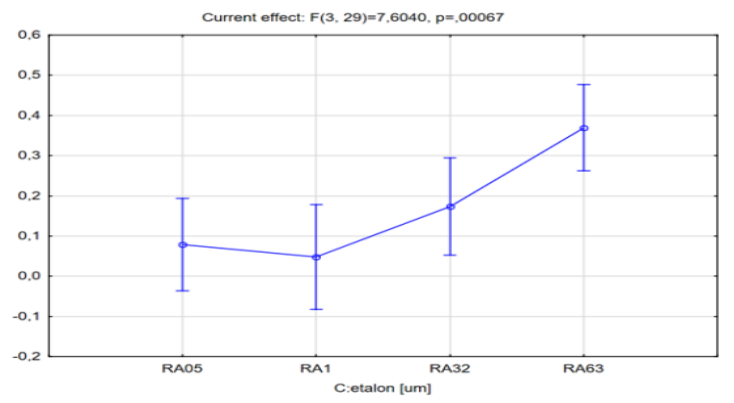

Fig. 17. Effect of 0601 filter after a change in surface roughness 
Due to the evaluation system used, the results for individual roughness numbers cannot be displayed in a single lucid graph. The data can be generated as graphs shown in Figures 12 through 16. Effects of individual filters are very difficult to compare using these graphs. Based on the above list of findings, a method of selection of software filters for surface roughness measurement was created. It is presented in Figure 17.

Although the results can be compared using Figures 12; 13 and 14, it is tedious to derive guidelines for choosing software filters for other surface roughness values. The graphs indicate that with series 16610 filters, standard deviations are very small, almost negligible. There are only very small differences between the results for individual roughness numbers obtained with these filters. In measuring a single roughness value, the variance of the measured data is very small. However, once the roughness measured changes, the differences increase considerably. The largest variance between different roughness values is found with filter 16610-22. With filters 0601 and 4768 , changes in roughness have an opposite effect. With these filters, standard deviations for a single roughness number are considerable. Once the roughness number changes, differences almost disappear, see graphs in Figures 15 and 16.

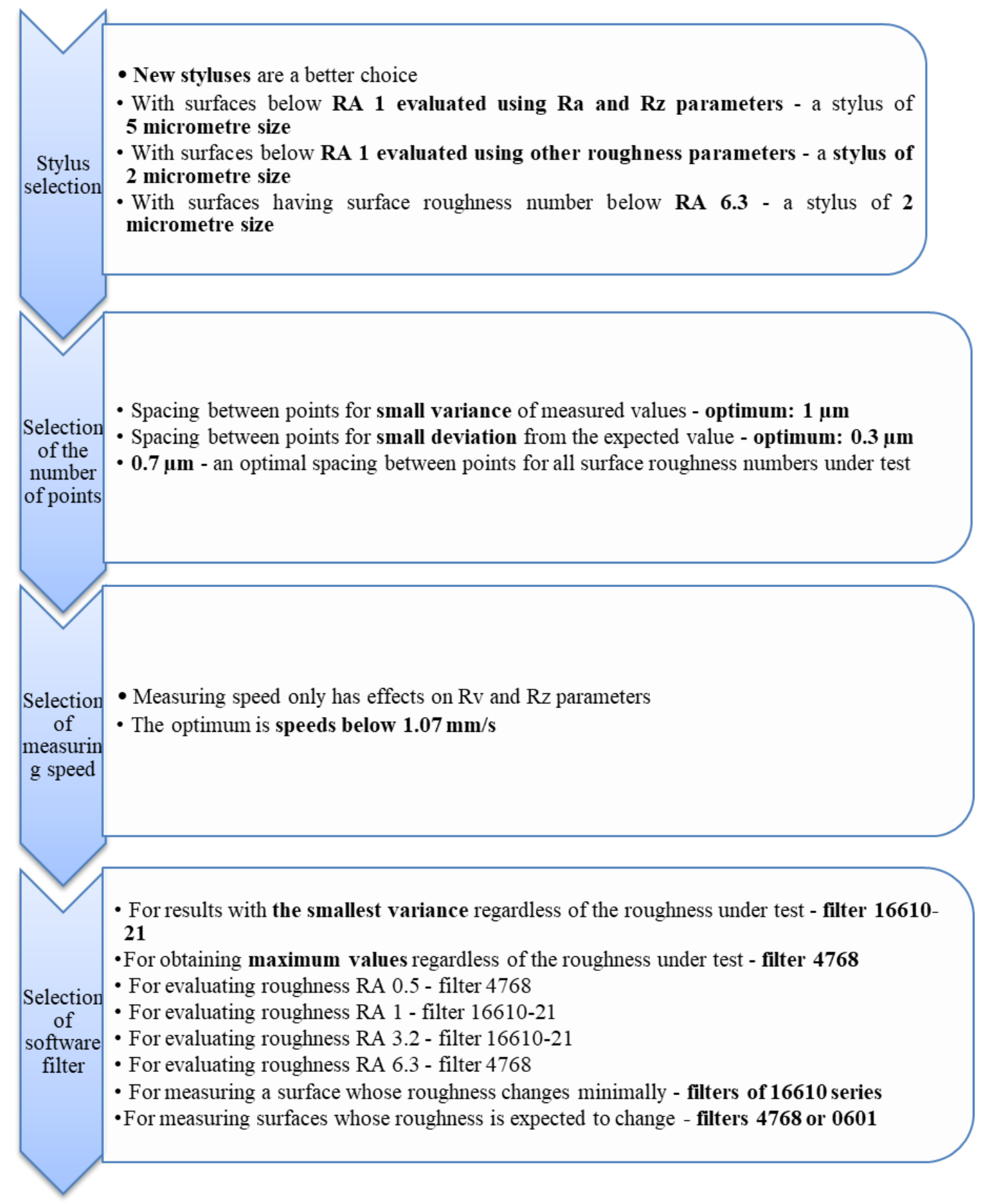

Fig. 18. Methodology of selection of software filter 
Example: For evaluating a surface, whose roughness is expected to be RA 0.5, using Ra and Rz parameters and a large number of measurements:

- a stylus with a size of 5 micrometres

- a number of points determined by their spacing of $1 \mu \mathrm{m}$

- $\quad$ measuring speed $0.5 \mathrm{~mm} / \mathrm{s}$

- $\quad$ filter 4768

\section{Conslusion}

Measurement and evaluation of surface structure have seen major qualitative advances in recent years. Leading producers of measuring instruments (Hommel CS s.r.o., Carl Zeiss spol. s.r.o. and others) have responded actively to new requirements. The evolution of measuring instruments is shaped by the technical needs of their users as well as by their financial strength. Surface structure is frequently checked by means of single-purpose measuring instruments. For this reason, some of those who put pressure on developing standards for evaluating the quality of measurement of machined surfaces are the manufacturers of such instruments themselves. [9]

This complex evolution has ultimately led to improved technologies of existing tools for surface structure measurement and analysis, as well as to better methods, measuring systems and the system of assessment and evaluation of surface structure that are still under development. [26] The system of assessment and evaluation of surface structure is defined by a body of standards which describe designations, measurement, and evaluation of surface structure, calibration of measuring instruments, and other aspects. They are the GPS standards which define geometric specifications of products. [9]

To meet all requirements for surface structure evaluation, it is necessary to keep up with the times and keep track of new opportunities and findings in measurement and surface integrity assessment. These findings then have to be implemented in practice. This was not the case in the field addressed by this dissertation, i.e. in selection of software filters. The main reason is the poor general awareness and the complexity of the selection of combinations of procedures and techniques for setting software filters.

This is why the objective of this dissertation was to establish a method of selection of software filters. To achieve the objective, the dissertation comprises 8 chapters. These 8 chapters are divided into four large units. The first unit (chapters 1 through 4) present the theoretical introduction into surface roughness measurement. This section defines the objective of the work and describes its motivation.

The second unit (chapter 5) reviews the theoretical background for designing the test of selection of software filters. The third unit (chapters 6 and 7) provides the key information in this dissertation. These chapters describe the tests which were carried out for establishing the method of selection of software filters and formulation of uncertainties of measurement. This work comprised three tests. Effects of selected settings of a measuring machine were tested which are required for developing a method of selection of software filters for roughness measurement.

The fourth unit comprises chapter 8. It gives a summary of all findings from the tests and the final verification of hypotheses constructed in the course of testing. Based on these findings, a method of selection of software filter for surface roughness measurement was created. The method consists of four steps. In the first step, the optimal stylus size should chosen. In the second step, the optimal spacing between measuring points must be selected. The third step involves selecting the speed of the stylus for measuring the primary profile. The fourth (last) step of the method concerns selection of a software filter, . If the surface structure is to be assessed correctly as part of surface integrity evaluation, none of these steps should be neglected.

All information reported in this dissertation applies to periodic surfaces. The same tests are planned to be performed on parts with non-periodic surfaces in order to compare and contrast the results. Implementation in practice will be sought for the resulting findings.

\section{Acknowledgments}

The article has been prepared in the project LO1502 'Development of the Regional Technological Institute' under the auspices of the National Sustainability Programme I of the Ministry of Education of the Czech Republic aimed to support research, experimental development and innovation.

\section{References}

[1] ČSN EN ISO 4288. Geometrické požadavky na výrobky (GPS) - Struktura povrchu: Profilová metoda - Pravidla a postupy pro posuzování struktury povrchu. 1. Brusel: CEN, 1999.

[2] ČSN EN ISO 3274. Geometrické požadavky na výrobky (GPS) - Struktura povrchu: Profilová metoda Jmenovité charakteristiky dotykových (hrotových) př́strojů. 1. Brusel: CEN, 1999.

[3] ČSN EN ISO 12085. Geometrické požadavky na výrobky (GPS) - Struktura povrchu: Profilová metoda Parametry metody motif. 1. Brusel: CEN, 1999. 
[4] ČSN EN ISO 13565-3. Geometrické požadavky na výrobky (GPS) - Struktura povrchu: Profilová metoda; povrchy mající stratifikované funkční vlastnosti - část 3: Výškové charakteristiky využívající pravděpodobností křivku materiálu. 1. Brusel: CEN, 2001.

[5] http://www.digitalsurf.fr/en/guidefiltrationtechniques.html[online]. [2016-06-27].

[6] http://nvlpubs.nist.gov/nistpubs/jres/120/jres.120.010.pdf[online]. [2016-06-27].

[7] http://eprints.hud.ac.uk/3980/1/p7.51_zeng.pdf[online]. [2016-06-27].

[8] http://mlg.eng.cam.ac.uk/pub/pdf/DeiTurHubetal12.pdf[online]. [2016-06-27].

[9] ČSN EN ISO 25178-2. Geometrická požadavky na výrobky (GPS) - Textura povrchu: Plocha - Část 2: Termíny, definice a parametry textury povrchu. Praha: unmz, 2012.

[10] ČSN EN ISO 16610-40. Geometricalproductspecification (GPS) - Filtration - Part 40: Morphological profile filter: Basic concepts, 2016. 